\title{
Phytochemical Profile of Aloe Barbadensis and their Proficiency in Defluoridation of Fluoride Contaminated Water
}

\author{
${ }^{1} \mathrm{M}$. Manopradesh, ${ }^{1 \times} \mathrm{N}$. Mathiyazhagan, ${ }^{2} \mathrm{~K}$. Gajendiran, ${ }^{1} \mathrm{R}$. Muthusamy, ${ }^{1} \mathrm{~K}$. Suresh and ${ }^{1} \mathrm{R}$. Selvam \\ ${ }^{1} \mathrm{PG}$ and Research Centre in Biotechnology, MGR College, Hosur, Krishnagiri, Tamil Nadu, India \\ 2Department of Microbiology, MGR College, Hosur, Krishnagiri, Tamil Nadu, India \\ Corresponding author mail id: mathimicro@gmail.com
}

\begin{abstract}
The quantitative analysis of acetone and ethanol extract of Aloe barbadensis were studied, the total flavonoid content was determined as $13 \mu \mathrm{g} / \mathrm{ml}$ in the acetone extracts of gel of the plant whereas in the ethanol extract, it was $30 \mu \mathrm{g} / \mathrm{ml}$ followed by total phenol content which was almost same in the extracts but found higher in acetone extract as $34 \mu \mathrm{g} / \mathrm{ml}$ it followed by ethanol extract as $32 \mu \mathrm{g} / \mathrm{ml}$. The reducing power assay was determined as $480 \mu \mathrm{g} / \mathrm{ml}$ in the ethanol extracts, followed by, $400 \mu \mathrm{g} / \mathrm{ml}$ in acetone extract. When Carbohydrates were compared, it was found as higher in the ethanol extract of the leaves of about $58 \mu \mathrm{g} / \mathrm{ml}$, whereas the acetone extract possessed $54 \mu \mathrm{g} / \mathrm{ml}$ of carbohydrates in the Aloe barbadensis. Ethanol extract of the gel found to easily absorb the carbohydrates easily compared to acetone. The proteins content of ethanolic extract was about $4.8 \mathrm{mg} / \mathrm{ml}$ followed by $4.2 \mathrm{mg} / \mathrm{ml}$ in the acetone extracts of leaves. In this test, acetone extract was observed to contain protein less than the ethanol. Unlike other tests, all the extracts of all the plant parts when measured showed more or less similar results of about 10 and $14.2 \mu \mathrm{g} / \mathrm{ml}$ of reducing sugars in the ethanol and acetone extracts of leaves. The DPPH activity in gel extract was observed to be present in both the extracts; higher activity was observed in ethanol $100 \mu \mathrm{l}$ concentrations and acetone $50 \mu \mathrm{l}$ concentrations. The Aloe barbadensis plant has found having some fluoride removal ability, helped in the fluoride removal process. As 20 $\mathrm{ml}$ concentration worked faster and better than the lower concentrations.
\end{abstract}

Keywords : Aloe barbadensis, Phytochemicals, Extracts, Flouride

\section{INTRODUCTION}

The plants are considered as important source of nutrition and as a result of that they are recommended for their therapeutic values. Some of these plants include ginger, green tea, walnuts, Aloe barbadensis, pepper and turmeric etc. [1]. Some plants and their derivatives are considered as important source for active ingredients which are used in aspirin and toothpaste etc. Apart from the medicinal uses, herbs are also used in natural dye, pest control, food, perfume, tea and so on. The Aloe barbadensis plant has been known and used for centuries for its health, beauty, medicinal and skin care properties. The name Aloe barbadensis derives from the Arabic word "Alloeh" meaning "shining bitter substance," while "vera" in Latin means "true." Today, the Aloe barbadensis plant has been used for various purposes in dermatology [2]. There are over several species of Aloe barbadensis grown around the world. However, only two species are grown today commercially, with Aloe barbadensis and Aloe aborescens being the most popular. Concentrated extracts of Aloe barbadensis leaves are used as laxative and as a haemorrhoid 
treatment because of their phytochemical properties [3]. An Aloe barbadensis plant usually produces optimally for five or six years, but may continue to produce at least twice as long. In commercial Aloe barbadensis plantations, three leaves of about one kilogram (two pounds) each in weight and $50-75 \mathrm{~cm}$ ( 20 - 30 inches) in length can be harvestable for three or four times a year [4]. Apart from antimicrobial activity of Aloe barbadensis, it also has the efficiency to remove the pollutant from the polluted environment [5]. With the exponential increase in population and deterioration in the water quality, the dependence on groundwater is increased to meet the water demand in rural as well as urban areas. However, the high exploration rate of groundwater and lowering of groundwater table the dependence on groundwater in deep aquifers is increasing [5]. Fluoride is one of the most abundant constituents occurring in the groundwater in many parts of the world, posing a potential threat to human health. The permissible limit of fluoride concentration in drinking water is $1.5 \mathrm{mg} / \mathrm{L}$ according to WHO guidelines. Among various methods used for defluoridation of water Adsorption method is relatively simple, economical, and appropriate for drinking water treatment. Aloe barbadensis along with $\mathrm{CaCl}^{2}$ has considerable amount of efficiency for the removal of fluorides from water $[6,7]$.

\section{METHODS AND MATERIAL}

\section{Sample collection}

The Aloe barbadensis, was identified and collected from Research and Development division of Genewin Biotech, Hosur, Krishnagiri. The water sample was collected as per the standard protocol from Hosur lake for the study of deflouridisation using Aloe barbadensis.

\section{Preparation of acetone and ethanol plant extracts}

The collected Aloe barbadensis samples was crushed to lotion form and it was soaked with $50 \mathrm{ml}$ of acetone and ethanol solvents separately. The whole mixture was extracted at room temperature for $48 \mathrm{hr}$. After the extraction period, the extracts were filtered with whatman filter paper and were stored at $4^{\circ} \mathrm{C}$ for further use.

\section{Qualitative Phytochemicals Analysis}

The total qualitative phytochemicals properties of acetone and ethanol extracts of Aloe barbadensis were analyzed by following the protocol of Ekwenye and Elegalam [8] and Olasupo et al., [9].

\section{Test for Alkaloids}

Wagner's test protocol was followed to quantify the total alkaloids of acetone and ethanol extracts of Aloe barbadensis. It was like $1 \mathrm{ml}$ of acetone and ethanol extracts $2 \mathrm{ml}$ of Wagner's reagent (iodine in potassium iodide) was added and the formation of reddish brown precipitate indicates the presence of alkaloids.

\section{Test for Saponins}

Small quantity of alcoholic and aqueous extracts was separately taken and $20 \mathrm{ml}$ of distilled water was added and agitated well in a graduated cylinder for 15 minutes. Formation of layer of foam indicates the presence of saponins.

\section{Test for Tannins}

To $1 \mathrm{ml}$ of the extract, $0.5 \mathrm{ml}$ ferric chloride solution was added; formation of a dark blue or greenish black color product shows the presence of tannins. The little quantity of the extract is treated with potassium ferric cyanide and ammonia solution. A deep red color indicates the presence of tannins. 


\section{Molisch's test}

To assess the existence of carbohydrate on both extracts of Aloe barbadensis were performed by taken $2 \mathrm{ml}$ of the extract, $1 \mathrm{ml}$ of a-napthol solution, and $0.5 \mathrm{ml}$ concentrated sulphuric acid were added gently through the side of the test tube. Purple or reddish violet color at the junction of the two liquids reveals the presence of carbohydrates.

\section{Test for Flavonoids}

Shinoda's Test protocol was followed as $0.5 \mathrm{gm}$ of each extract was treated with sodium hydroxide and the formation of yellow color indicates the presence of flavones. Another method was performed as for conformation, the extract was treated with concentrated $\mathrm{H}_{2} \mathrm{SO}_{4}$, formation of yellow or orange color indicates flavones.

\section{Quantitative analysis:}

\section{Determination of Carbohydrate}

$100 \mathrm{mg}$ of sample was hydrolysed in a boiling tube with $5 \mathrm{ml}$ of $2.5 \mathrm{~N} \mathrm{HCl}$ in a boiling water bath for a period of 3 hours. It was cooled to room temperature and solid sodium carbonate was added until effervescence ceases. The contents were centrifuged and the supernatant was made to $100 \mathrm{ml}$ using distilled water. From this $0.2 \mathrm{ml}$ of sample was pipetted out and made up the volume to $1 \mathrm{ml}$ with distilled water. Then $1.0 \mathrm{ml}$ of phenol reagent was added followed by $5.0 \mathrm{ml}$ of sulphuric acid. The tubes were kept at $25-30^{\circ} \mathrm{C}$ for $20 \mathrm{~min}$. The absorbance were read at $490 \mathrm{~nm}$ [10].

\section{Determination of Protein}

The extracts were stirring with $50 \mathrm{ml}$ of $50 \%$ methanol $(1: 5 \mathrm{w} / \mathrm{v})$ at $25{ }^{\circ} \mathrm{C}$ for $24 \mathrm{~h}$ and centrifuged at $7,000 \mathrm{rpm}$ for $10 \mathrm{~min} .0 .2 \mathrm{ml}$ of extract was pipetted out and the volume was made to $1.0 \mathrm{ml}$ with distilled water. $5.0 \mathrm{ml}$ of alkaline copper reagent was added to all the tubes and allowed it to stand for 10 min. Then $0.5 \mathrm{ml}$ of Folin's Ciocalteau reagent was added and incubated in dark for $30 \mathrm{~min}$. The intensity of the colour developed was read at $660 \mathrm{~nm}$.

\section{Determination of Total Phenolics}

The total phenolic content was determined according to the method described by Cavallini et al., [11] as $10 \mu \mathrm{l}$ aliquots of the extracts $(2 \mathrm{mg} / 2 \mathrm{ml})$ was taken in test tubes and made up to the volume of $1 \mathrm{ml}$ with distilled water. Then $0.5 \mathrm{ml}$ of Folin-Ciocalteu phenol reagent (1:1 with water) and $2.5 \mathrm{ml}$ of sodium carbonate solution (20\%) were added sequentially in each tube. Soon after vortexing the reaction mixture, the test tubes were placed in dark for $40 \mathrm{~min}$ and the absorbance was recorded at $725 \mathrm{~nm}$ against the reagent blank. The analysis was performed in triplicate and the results were expressed as tannic acid equivalents [11].

\section{Determination of Total Flavonoid Content}

The flavonoid content was determined by the use of a slightly modified colorimetry method of Cavallini et al., [11], as $0.5 \mathrm{ml}$ aliquot of appropriately $(2 \mathrm{mg} / 2 \mathrm{ml})$ diluted sample solution was mixed with $2 \mathrm{ml}$ of distilled water and subsequently with $0.15 \mathrm{ml}$ of $5 \%$ $\mathrm{NaNO}_{2}$ solution. After $6 \mathrm{~min}, 0.15 \mathrm{ml}$ of $10 \% \mathrm{AlCl}_{3}$ solution was added and allowed to stand for $6 \mathrm{~min}$, and then $2 \mathrm{ml}$ of $4 \% \mathrm{NaOH}$ solution was added to the mixture. Immediately, water was added to bring the final volume to $5 \mathrm{ml}$, and then the mixture was thoroughly mixed and allowed to stand for another 15 min. Absorbance of the mixture was determined at $510 \mathrm{~nm}$ versus water blank. The analysis was performed in triplicate and the results were expressed as routine equivalent [11].

\section{DPPH Free Radical Scavenging Assay}

The radical scavenging activity of selected root extracts was determined by following the method of Heggers et al., [12]. As 4.3mg of DPPH (2, 2-Diphenyl -1- picrylhydrazyl) was dissolved in methanol $(6.6 \mathrm{ml})$ to prepare $0.3 \mathrm{mM}$ DPPH solution and it was 
protected from light by covering the test tubes with

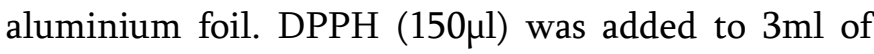
methanol and absorbance was noticed immediately at $516 \mathrm{~nm}$ for control reading. Different concentrations of test samples i.e $25 \mu \mathrm{l}, 50 \mu \mathrm{l}, 100 \mu \mathrm{l}, 150 \mu \mathrm{l}, 200 \mu \mathrm{l}$ and $250 \mu \mathrm{l}$ were taken and each of the samples was diluted with methanol up to $3 \mathrm{ml}$, to it $150 \mu \mathrm{l} \mathrm{DPPH}$ was added. The samples were kept in dark for $15 \mathrm{~min}$ after which the optical density was observed at $516 \mathrm{~nm}$ using methanol as blank.

(Control Absorbance Sample Absorbance)

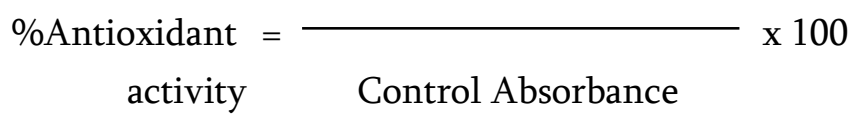

\section{Determination of Total Reducing Power}

The reducing power was determined according to the method of Heggers et al., [12]. As $1 \mathrm{ml}$ of the extract $(1 \mathrm{mg} / \mathrm{ml})$ was mixed with $1 \mathrm{ml}$ of $200 \mathrm{mM}$ of sodium phosphate buffer ( $\mathrm{pH}-6.6)$ and $1 \mathrm{ml}$ of $1 \%$ potassium ferricyanide. The mixture was incubated at $50^{\circ} \mathrm{C}$ for $20 \mathrm{~min}$ and $1 \mathrm{ml}$ of $10 \%$ trichloroacetic acid (w/v) was added. The mixture was centrifuged at 2000rpm for $10 \mathrm{~min}$. The upper layer solution $(2.5 \mathrm{ml})$ was mixed with $2.5 \mathrm{ml}$ of double deionised water and $1 \mathrm{ml}$ of fresh ferric chloride solution $(0.1 \%)$. The absorbance was measured at $700 \mathrm{~nm}$. A higher absorbance indicates a higher reducing power.

\section{Water Analysis - Regular Interval of Time}

The defluoridation efficiency of acetone and ethanol extracts of Aloe barbadensis were analyzed on fluoride enriched water. It was collected from Hosur lake. The collected samples were immediately transferred to lab and refrigerated for further analysis and standard protocol was used for all analysis.

\section{Water Hardness}

The hardness of the water sample was analysed by following the standard protocol. As $20 \mathrm{ml}$ of sample was taken in a conical flask and added $2 \mathrm{~mL}$ of ammonia buffer solution (so that $\mathrm{pH}$ will be maintained b/w 9 \&10), subsequently few drops of EBT indicator was added and the sample turns into wine red in color. Rinsed the burette with few $\mathrm{ml}$ of EDTA before titrating and filled the burette with 0.02 $M$ EDTA solution. Then the sample was titrated against the EDTA solution till the appearance of blue color.

\section{Sulfate Determination in Water}

$50 \mathrm{~mL}$ of Filtered (Whatman No. 1) water sample was taken in an Erlenmeyer flask and added $20 \mathrm{ml}$ of buffer solution and mix in stirring apparatus. While stirring, $0.15 \mathrm{~g}$ of barium chloride was added to the sample and stirs the sample with the help of magnetic stirrer for about an hour. After the incubation period the absorbance of test sample was analyzed against standard solution/distilled water (without barium chloride) at $420 \mathrm{~nm}$ using spectrophotometer. The obtained OD values are applied for graph with by using concentration on $\mathrm{X}$-axis and absorbance at 420 $\mathrm{nm}$ on $\mathrm{Y}$-axis.

\section{Chloride Determination in Water}

$10 \mathrm{ml}$ of the test sample was taken in conical flask and added $0.05 \mathrm{ml}$ of iodine reagent. Then titrated the contents quickly against sodium thiosulphate $(0.2482 \mathrm{~g}$ in $100 \mathrm{ml})$ until the colour turns straw yellow. Later, $1 \mathrm{ml}$ of starch (1\%) was added to the conical flask, it turns the turns straw yellow colour to blue. Continued the titration until the sample turns colourless. Then calculate the residual chlorine from titre value. 
Chemical Oxygen Demand (COD) Electrical Conductivity (EC) \&Total Dissolved Solids (TDS) \& $\mathrm{pH}$

The Chemical Oxygen Demand, electrical conductivity, TDS and $\mathrm{pH}$ of the water was determined in a quick and inexpensive way by using standard commercial portable meters [11].

\section{Fluoride determination}

The fluoride level of water sample was anaysed by following the method of Massoud Amanlou, et al., [13]. As $10.0 \mathrm{~mL}$ sample was taken and mixed with $10.0 \mathrm{ml}$ of TISAB II; after that, fluoride concentrations of test samples were determined in duplicate using fluoride ion selective electrode. One batch number (out of six) for each of the 18 bottled drinking waters was randomly selected and the samples re-analyzed to assess the reliability of the method [13].

\section{Defluoridization}

The defluoridization experiment was performed by following the protocol of Sneha Jagtap, et al., [14]. Various doses as 5, 10, 15 and $20 \mathrm{ml}$ of Aloe barbadensis gel were added on $100 \mathrm{ml}$ fluoride contaminated water. The gel applied water was kept for 15 days of treatment period. The effect of gel on water sample was assessed by analyses the various parameters such as fluoride, $\mathrm{pH}, \mathrm{EC}$, TDS, Hardness, COD and sulfate during the pre and post of the treatment in intermittence of 0,7 and 15 days of treatment period. Obtained results were compared with Indian standard permissible limits.

\section{RESULTS AND DISCUSSION}

\section{Results}

\section{Phytochemical analysis}

The phytochemical analysis was carried out to qualify either the presence or absence of alkaloids, saponins, carbohydrates, tannins and flavonoids from acetone and ethanol extracts of Aloe barbadensis and the results were tabulated table 1 .

At the end of phytochemical qualitative analysis, the results showed that the ethanol extract contains almost all the tested ingredients except fats and oils. The acetone extracts shows the all the components except fats and oils.

Table 1 : Phytochemical analysis of acetone and ethanol extracts of Aloe barbadensis

\begin{tabular}{|c|l|c|c|}
\hline S.No. & Phytochemicals & Acetone & Ethanol \\
\hline 1 & Saponins & + & + \\
\hline 2 & $\begin{array}{l}\text { Alkaloids } \\
\text { Wagner's Test }\end{array}$ & + & + \\
\hline 3 & Fats and oils & - & - \\
\hline 4 & $\begin{array}{l}\text { Carbohydrates } \\
\text { Molisch's Test }\end{array}$ & + & + \\
\hline 5 & $\begin{array}{l}\text { Tannins } \\
\text { Lead acetate } \\
\text { Ferric chloride }\end{array}$ & + & + \\
\hline 6 & $\begin{array}{l}\text { Flavonoids } \\
\text { Shinoda's Test } \\
\left(\text { H2SO }_{4}\right)\end{array}$ & + & + \\
\hline
\end{tabular}

The results of the flavonoid content of the acetone and ethanol extracts were found as follows. The 13 $\mu \mathrm{g} / \mathrm{ml}$ of flavonoid was recorded in the acetone extracts of gel of the Aloe barbadensis plant. Whereas, in the ethanol extract of Aloe barbadensis, was double fold quantity of flavonoids as $30 \mu \mathrm{g} / \mathrm{ml}$. According to the result obtained, leaves of ethanol extract showed have higher Flavonoids content than acetone (Fig. 1). 


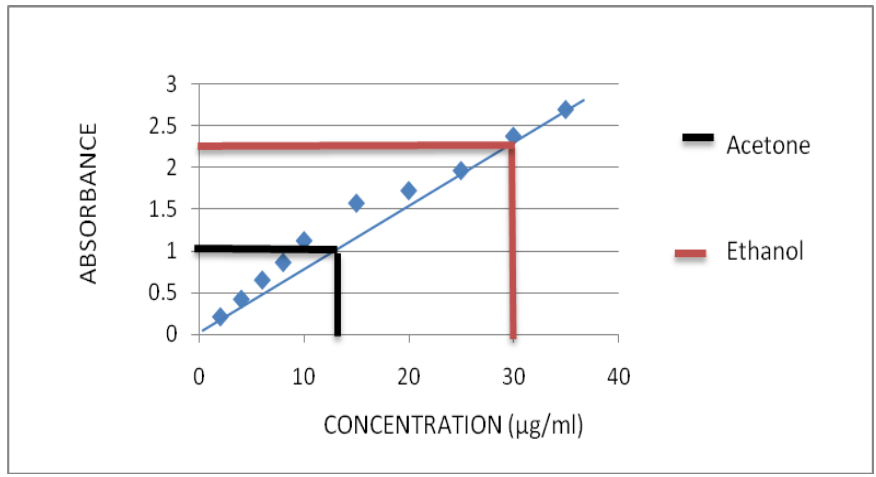

Figure 1 : Total flavonoids content of acetone and ethanol extracts

The phenolics content of acetone and ethanol extracts were determined at $725 \mathrm{~nm}$ using Gallic acid as standard and the quantity of phenolics represented as figure 2.

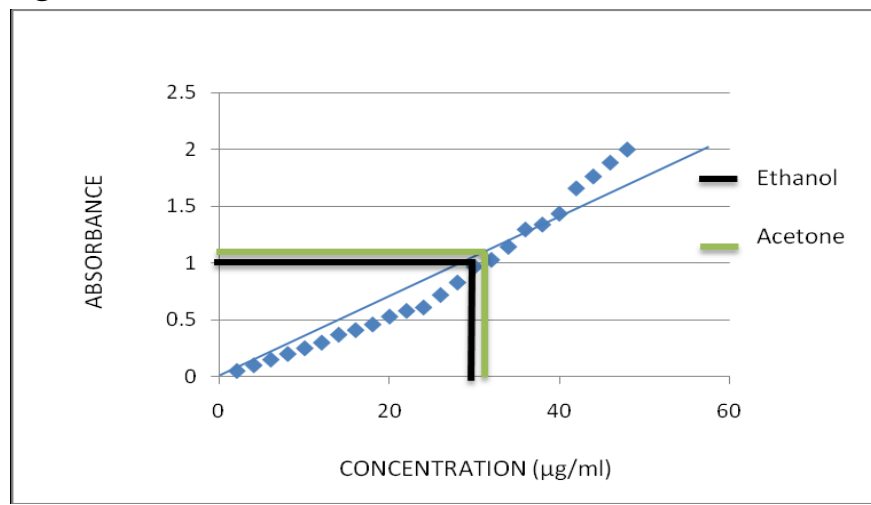

Figure 2 : Total Phenolic content of acetone and ethanol extracts

From the standard graph, total Phenol content was almost same in the both extracts but found higher in acetone extract as $34 \mu \mathrm{g} / \mathrm{ml}$, it followed by ethanol extract as $32 \mu \mathrm{g} / \mathrm{ml}$ of phenolic content was observed.

The reducing sugar of the both extracts was reported as $480 \mu \mathrm{g} / \mathrm{ml}$ in the ethanol extract of leaves gel followed by $400 \mu \mathrm{g} / \mathrm{ml}$ in acetone extract of the leaves gel. The results compared with each solvent by drawn picture as follows (Fig. 3)

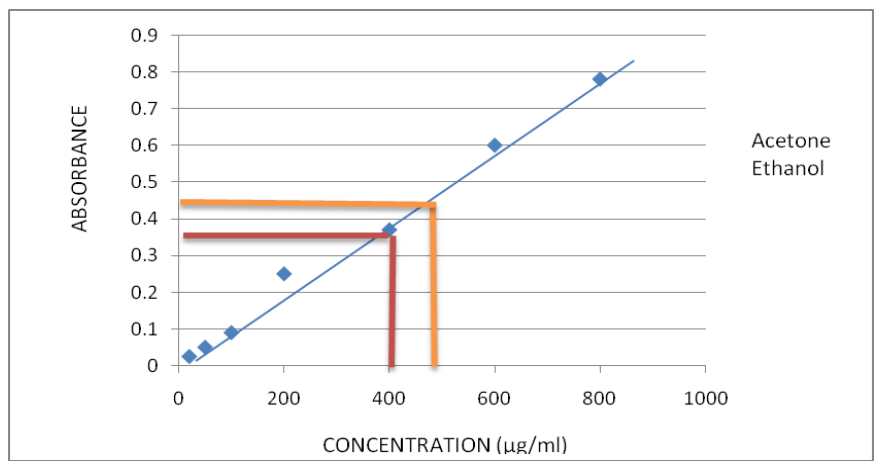

Figure 3 : Reducing power assay of acetone and ethanol extracts

In the carbohydrate analysis, the obtained reports are stated that the carbohydrates were found as higher in the ethanol extract about $58 \mu \mathrm{g} / \mathrm{ml}$ whereas, the acetone extract was observed to possess $54 \mu \mathrm{g} / \mathrm{ml}$ of carbohydrates in the leaves. Ethanol extract of the gel found to easily absorb the carbohydrates (Fig. 4).

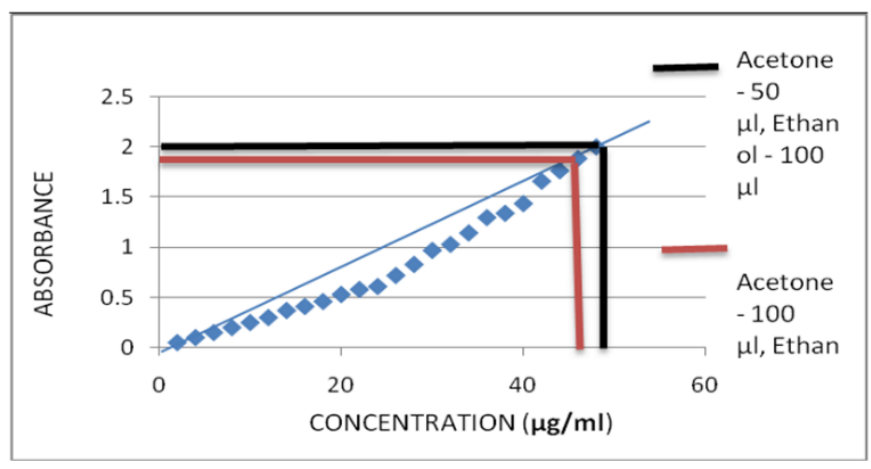

Figure 4 : Carbohydrate content of acetone and ethanol extracts

Proteins are compared in the collected sample extracts to know the amount of proteins present in the Aloe barbadensis along with BSA used as standard.

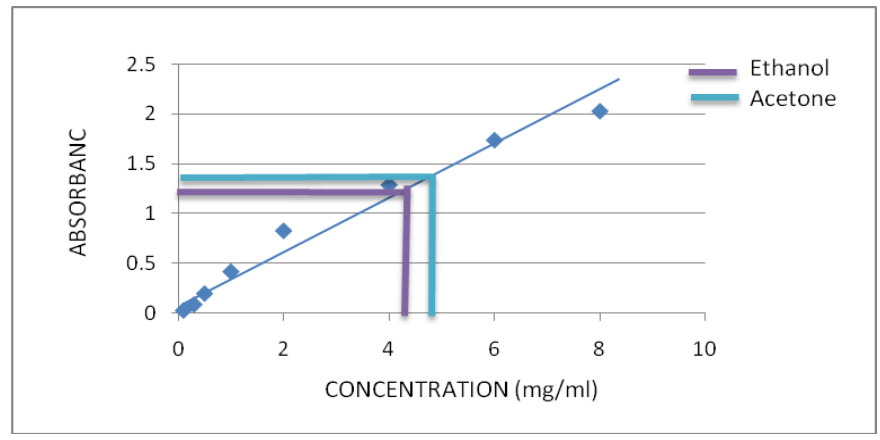

Figure 5: Protein content of acetone and ethanol extracts 
The proteins were measured higher in the ethanol extract of Aloe barbadensis about $4.8 \mathrm{mg} / \mathrm{ml}$ followed by $4.2 \mathrm{mg} / \mathrm{ml}$ in the acetone extracts (Fig. 5). Reducing sugars in Aloe barbadensis samples were measured at $575 \mathrm{~nm}$ and glucose was used as standard. The result was noted that all the extracts of Aloe barbadensis showed more or less similar results of about 10 and $14.2 \mu \mathrm{g} / \mathrm{ml}$ of reducing sugars in the ethanol and acetone extracts respectively (Fig. 6).

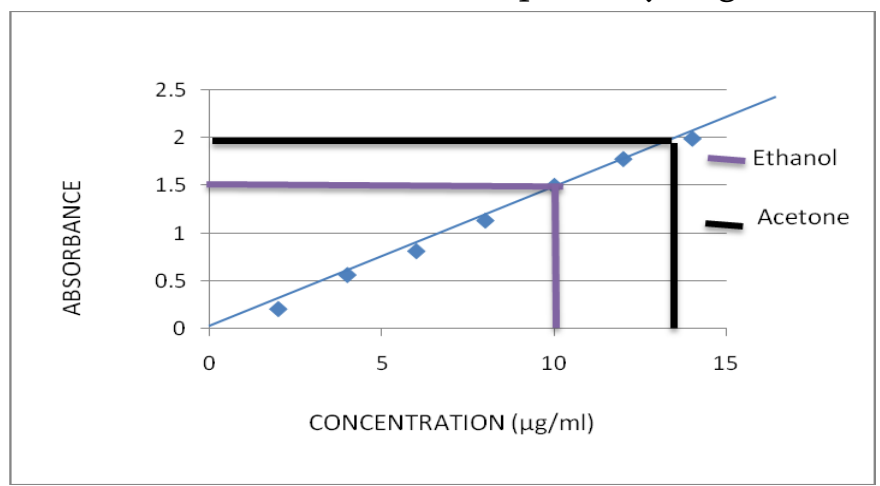

Figure 6 : Reducing sugar of acetone and ethanol extracts

\section{DPPH Radical Scavenging activity}

The DPPH activity of both extracts were reported as, the higher activity was observed in ethanol $100 \mu \mathrm{l}$ concentration and it followed by acetone $50 \mu \mathrm{l}$ concentration (Fig. 7).

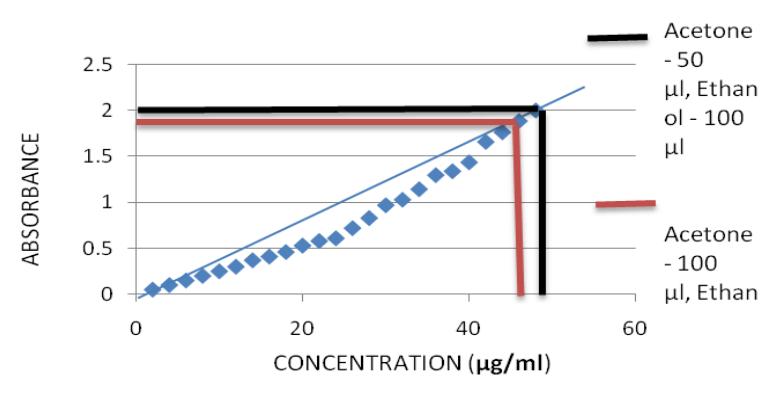

Figure 7 : DPPH radical scavenging activity of acetone and ethanol extracts

\section{Defluoridation by gel of Aloe barbadensis}

The defluoridation of fluoride contaminated water by gel of Aloe barbadensis was determined and tabulated in table 2. The analysis table clearly proves the efficiency of Aloe barbadensis gel in fluoride reduction, as we precede the experiment for a 15 days treatment, the fluoride becomes reduced as on $7^{\text {th }}$ days fluoride was $4.4 \mathrm{mg} / \mathrm{ml}$ on $20 \mathrm{ml}$ concentration and on $15^{\text {th }}$ day it reduced as $3.2 \mathrm{mg} / \mathrm{ml}$ on same $20 \mathrm{ml}$ dosage of Aloe barbadensis gel. It conforms that the gel of Aloe barbadensis has the efficiency to the defluoridation process. The remaining parameters such as EC, TDS, hardness, COD and quantity of sulfates are also reduced during the 15 days treatment period.

Table 2 : Defluoridation by gel of Aloe barbadensis

\begin{tabular}{|c|c|c|c|c|c|c|c|}
\hline \multirow{3}{*}{$\begin{array}{l}\text { Various concentration } \\
(\mathrm{ml}) \text { of Aloe } \\
\text { barbadensis gel }\end{array}$} & \multirow{2}{*}{$1-1.5 \mathrm{mg} / 1$} & \multicolumn{6}{|c|}{ Permissible limits } \\
\hline & & $6.5-8.5$ & $<1000$ & $<500$ & $<60$ & $<100$ & $<200$ \\
\hline & Fluoride & $\mathrm{pH}$ & EC & TDS & $\begin{array}{c}\text { Hard } \\
\text { ness }\end{array}$ & COD & Sulfates \\
\hline 0 & 8.9 & 7.8 & 860 & 480 & 340 & 430 & 215 \\
\hline \multicolumn{8}{|c|}{ DAY 7} \\
\hline 20 & 4.4 & 7 & 780 & 320 & 250 & 360 & 156 \\
\hline 15 & 4.7 & 7.1 & 834 & 480 & 336 & 410 & 167 \\
\hline 10 & 5.3 & 7.2 & 812 & 485 & 343 & 398 & 189 \\
\hline 5 & 7.3 & 7.4 & 854 & 475 & 349 & 393 & 201 \\
\hline \multicolumn{8}{|c|}{ DAY 15} \\
\hline 20 & 3.2 & 6.5 & 630 & 189 & 80 & 128 & 110 \\
\hline 15 & 3.6 & 6.98 & 690 & 270 & 165 & 352 & 115 \\
\hline 10 & 4.9 & 7.12 & 684 & 280 & 173 & 248 & 180 \\
\hline 5 & 6.3 & 7.28 & 754 & 354 & 251 & 352 & 187 \\
\hline
\end{tabular}




\section{Discussion}

The Aloe barbadensis is a shrubby, perennial, xerophytic, succulent plant. It has thick and pulpy leaves. It belongs to Liliaceae family. The medicinal importance of Aloe barbadensis plants has been well known for centuries. The whole Aloe plant has been used as a stomachic, antihelmintic and emmenagogue, menstrual suppression and the root for colic pain etc because of their phytochemical components [10]. It have number of nutrients such as sugars, minerals (iron, zinc, sodium, potassium, calcium, magnesium etc.), amino acids, enzymes, fatty acid etc. In this study, Aloe barbadensis gel was aimed at the analysis of phytochemicals using 2 solvents such as Acetone and Ethanol which proved the presence of plant phytochemicals and followed by the antioxidant activity tests which showed the highest activity in both the solvents. Aloe barbadensis gel can be useful richly for topical applications, wide ranges of products are now available on the market; however, simply pure Aloe gel is sufficient to treat several skin disorders. Apart from their medicinal uses because of phytochemical content, they also possess the efficiency to remediation process on contaminated water [15]. The force responsible for precipitation and adsorption of fluoride with Aloe barbadensis and calcium chloride is supposed to be some columbic forces between the positively charged surface and negatively charged fluoride ions. Most probably, the calcium ions in Aloe barbadensis and calcium chloride react with negatively charged fluoride ions from the solution.

The probable responsible ion in this process may be the hydrogen ion. It accelerates the positive charge on calcium which favors the precipitation and adsorption of fluoride. The main mechanism may be through fluoride precipitation and adsorption ( $\mathrm{CaF} 2)$ by Aloe barbadensis and calcium chloride as well as filtered through local available Sikar clay. The optimum fluoride removal (88\%) was achieved at $\mathrm{pH} 7.4 \pm 0.1$ with $40.0 \mathrm{~g}$ Aloe barbadensis, $3.0 \mathrm{~g}$ calcium chloride in $1000 \mathrm{ml}$ sample and in a contact period of 40 minutes [6].

Many plants and herbs have been studied and analysed for their fluoride removal capacity. The Aloe barbadensis plant has found having some fluoride removal capacity. Local lake water was selected for the confirmation of Aloe barbadensis gel efficiency in fluoride removal which examined for fluoride removal at various concentrations of ale gel and showed sharp reduction of all the parameters such as EC, TDS, hardness, COD and quantity of sulfates in 15 days.

The fluoride becomes reduced as on 7th days the fluoride was $4.4 \mathrm{mg} / \mathrm{ml}$ on $20 \mathrm{ml}$ concentration and on 15 th day it reduced as $3.2 \mathrm{mg} / \mathrm{ml}$ on same $20 \mathrm{ml}$ dosage of Aloe barbadensis gel. It conforms that the gel of Aloe barbadensis has the efficiency to the defluoridisation process. Similar kind of study was performed by Radhey Shyam and Kalwania [6], they have been used the Aloe barbadensis and calcium chloride to precipitate out fluoride ions from drinking water.

\section{Conclusion}

The overall results concluded that the Aloe barbadensis gel has number of phytochemical ingredients. Further it also has water purification properties. The Aloe barbadensis plant has found having some fluoride removal capacity, helped in the fluoride removal process. Since plants are available naturally, the phytoremediation method can be adopted instead of chemical treatment for the benefit of the humans.

\section{Acknowledgement}

The authors would like to thank the department of Biotechnology, M.G.R. College, Hosur for providing 
laboratory support for successful completion of this research work.

\section{REFERENCES}

[1]. Toplak Galle K, Domestic medicinal plants. Zagreb. Mozaic book. 2005; 60-1.

[2]. Kelly K, History of medicine. New York: Facts on file. 2009; 29-50.

[3]. West DP, Zhu YF, Evaluation of Aloe barbadensis gel gloves in the treatment of dry skin associated with occupational exposure. Ame J Infect Control. 2003; 31: 40-42.

[4]. Chang, J, Scientific evaluation of traditional Chinese medicine under DSHEA: A conundrum. J. Altern. Complem. Med, 1999; 5: 181-189

[5]. Dwivedi A.K, Arsenic in Groundwater: An Issue beyond Boundary. Biodiversity conservation and sustainable development center for biological research, puthalam, Tamil Nadu, India. 2013; 3: 30-43.

[6]. Radhey shyam, Kalwania G. S, Removal of fluorides in drinking water by Aloe vera and calcium chloride. Chem Sci Trans. 2014; 3 (1): 29-36

[7]. Telkapalliwar N.G, Shivankar V. M, Review on adsorption of fluoride from aqueous solution by using low cost leaf based bioadsorbents, Inter J Mod Trend Engi Res. 2016; 3 (6): 40-52.

[8]. Ekwenye U.N, Elegalam N.N, 2005 Antibacterial activity of ginger (Zingiber officinale Roscoe) and garlic (Allium sativum L.) extracts on Escherichia coli and Salmonella typhi. J. Mol. Med. Adva. Sci. 2005; 1: 411-416.

[9]. Olasupo A.D, Aborisade A.B, Olagoke O.V, Phytochemical Analysis and antibacterial Activities of Spinach Leaf. Amer J Phytomed Clin Thera 2018; 6: 2-8.

[10]. Velcheva, Regeneration was also achieved through somatic organogenesis using young immature inflorescences, in which efficient regeneration was initiated on MS medium supplemented with BA or TDZ. J Mod Trend Engi Res. 2005; 4: 40-50.

[11]. Cavallini A, Natali L, Castorena Sanchezi, Aloe barbadensis Mill. In: Bajaj YPS. Biotech. Agri Fores. 1991; 15: 95-106.

[12]. Heggers J, Kucukcelebi A, Listengarten D, Stabenau J, Ko F, Broemeling LD, Beneficial effect of Aloe barbadensis on wound healing in an excisional wound model. J Altern Complem Med 1996; 2: 271-7.

[13]. Massoud Amanlou, Maedeh Hosseinpour, Homa Azizian, Mohammad Reza Khoshayand, Mojtaba Navabpoor, Effat Souri, Determination of fluoride in the bottled drinking waters in Iran. Iran. J. Pharm. Res. 2010; 9 (1): 37-42.

[14]. Sneha Jagtap, M. K. N, Yenkie, Nitin Labhsetwar, Sadhana Rayalu, Fluoride in Drinking Water and Defluoridation of Water. Chem Rev. 2012; 112 (4):2454-66

[15]. Huq SI, Bulbul A, Choudhury MS, Alam S, Kawai S, Arsenic bioaccumulation in a green algae and its subsequent recycling in soil of Bangladesh. Natural Arsenic in Groundwater: Occurrence, Remediation and Management. 2004; 1: 119-24.

\section{Cite this article as :}

M. Manopradesh, N. Mathiyazhagan, K. Gajendiran, R. Muthusamy, K. Suresh, R. Selvam, "Phytochemical Profile of Aloe Barbadensis and their Proficiency in Defluoridation of Fluoride Contaminated Water", International Journal of Scientific Research in Science and Technology (IJSRST), Online ISSN : 2395-602X, Print ISSN : 2395-6011, Volume 6 Issue 6, pp. 156-164, November-December 2019. Available at doi : https://doi.org/10.32628/IJSRST196614 Journal URL : http://ijsrst.com/IJSRST196614 